\title{
Improve Quality Of Alfalfa Silage Ensiled With Orange Pulp And Bacterial Additive
}

\author{
Maghsoud BESHARATI ${ }^{1}$, Mojtaba KARIMI ${ }^{2}$, Akbar TAGHIZADEH $^{3}$, Zabihollah NEMATI ${ }^{4}$, Ali KAYGISIZ ${ }^{5}$ \\ 1,2,3,4University of Tabriz, Ahar Faculty of agriculture and Natural resources, Department of Animal Science, 51666, Tabriz, Iran, \\ ${ }^{5}$ Kahramanmaraş Sütçü İmam Üniversity Agriculture Faculty Animal Science Department Kahramanmaraş \\ ${ }^{1}$ https://orcid.org/0000-0002-5233-6425, ${ }^{2}$ https://orcid.org/0000-0002-7495-7150, ${ }^{3}$ https://orcid.org/0000-0002-9120-1662, \\ ${ }^{4} \mathrm{https}: / /$ orcid.org/0000-0001-8842-012X, ${ }^{5} \mathrm{https}: / /$ orcid.org/0000-0002-5302-2735 \\ 凹: m_besharati@hotmail.com
}

\section{ABSTRACT}

This study evaluated the effects of Lactobacillus buchneri (LAB) and orange pulp (OP) supplementation on chemical composition, in vitro and in situ degradability, dry matter (DM), $\mathrm{pH}$ and aerobic stability of alfalfa silage. Treatments were 1) alfalfa without any additive (control), 2) alfalfa + OP $(70 \%$ alfalfa mixed with $30 \%$ fresh OP, LAB0), 3) treatment 2 with $1.5 \mathrm{~g} \mathrm{LAB} /$ ton (LAB1), 4) treatment 2 with $3 \mathrm{~g} \mathrm{LAB} /$ ton (LAB2) and 5) treatment 2 with $4.5 \mathrm{~g} \mathrm{LAB} /$ ton (LAB3). Treatments were replicated three times in laboratory mini silos for $90 \mathrm{~d}$ in a closed barn with a ambient temperature (15 to 18 $\left.{ }^{\circ} \mathrm{C}\right)$. As a result of this study, the experimental treatments did not affect on DM of silage at the end of the ensiling period. Control treatment had the highest $\mathrm{pH}$ (4.5) among the experimental treatments $(\mathrm{P}<0.05)$. Supplementation alfalfa with $\mathrm{OP}$ resulted in significant increase in water soluble carbohydrate (WSC) and total volatile fatty acids (VFAs) $(\mathrm{P}<0.05)$. Treating alfalfa silage with OP and LAB improved aerobic stabilities of treatments significantly, as compared to LAB0. Supplementation of silage with OP and bacterial inoculant increased DM digestibility. These findings indicated that LAB can improve the aerobic stability and quality of silage in laboratory silos and also, OP and LAB might improve silage quality and cause better silage management in the farm.

Research Article
$\begin{array}{ll}\text { Article History } \\ \text { Received } \quad: 11.01 .2020 \\ \text { Accepted } \quad: 04.06 .2020\end{array}$

\author{
Keywords \\ Aerobic stability \\ Alfalfa silage \\ Bacterial additive \\ Lactobacillus Buchneri \\ Orange pulp
}

To Cite : Besharati M, Karimi M, Taghizadeh A, Nemati Z, Kaygisız A 2020. Improve Quality Of Alfalfa Silage Ensiled With Orange Pulp And Bacterial Additive. KSU J. Agric Nat 23 (6): 1669-1677. DOI: 10.18016/ksutarimdoga.vi.673623.

\section{INTRODUCTION}

Improving rumen condition and production in livestock production farms is dependent on improving the conditions for digestion of the fiber (Jalc et al. 2009; Hashemzadeh et al. 2011,). Alfalfa in dry condition is more used than silage, which in some cases accounts for more than half of the ration (Delavar et al. 2004; Kowsar et al. 2008; Soltani et al. 2009, Hashemzadeh et al. 2011). However, alfalfa silage is commonly used in dairy ration to benefit production (Benchaar et al., 2007). Especially, silage of legumes compared to dried herbs milk they have higher feeding value for their cows (Mut et al., 2020). Recent 30 to 40 years, the addition of carbohydrate and bacterial additives to improve the quality of the silage has been studied. Citrus pulp, tomato pomace, apple pomace and pistachio pulp are among the byproducts of the agricultural and processing industries that are introduced as a potential source of livestock feeding (Alnaimy et. al., 2017; Ayaşan and İnci, 2019). These materials are produced in the respective factories depending on the season of production of fruit and are largely disposed of without contaminating the environment (Karimi et al. 2017).

Applying technically appropriate silage making procedure is prerequisite to obtain a high-quality silage. In addition, variability of silage micro flora, their interaction and growth in silo are main factors affecting silage quality

Exposure of silage to the air at the time of feeding causes deterioration of the silage. Yeasts that are able to metabolise lactic acid are the first cause of deterioration, which causes a rise in $\mathrm{pH}$ (Kleinschmit and Kung 2006; Jalc et al. 2010), which is also a stimulant for the growth of other harmful microorganisms in the silage (Sadegni et al. 2012; Anonim 2016). These unwanted reduces livestock production due to food depreciation or poisoning. It was showed that use of Lactobacillus buchneri improves aerobic stability of silage (Kleinschmit and Kung 2006). Many studies have been carried out by many researchers on this microorganism, which has proven that Lactobacillus buchneri, by converting lactic acid to acetic acid, increases the resistance of silage to aerobic corrosion (Oude et. al 2001; Kleinschmit and Kung 2006; Sadegni et al. 2012). 
This study evaluated the effects of Lactobacillus. buchneri 40788 inoculants on the dry matter (DM) content $\mathrm{pH}$, aerobic stability and microbial population in alfalfa with fresh orange pulp silage.

\section{MATERIALS and METHODS}

Whole fourth cut alfalfa was harvested in the prebloomed stage (Ahar town, Iran, late september of 2016) at DM of $22 \%$ and with orange pulp chapped manually with a theoretical size of 2.5 centimeters and wilted at room temperature for $24 \mathrm{~h}$. Chemical composition of wilted alfalfa and OP before ensiling are given in Table 1.

Table 1. Chemical characteristics of alfalfa and orange pulp before ensiling (\% of DM)

\begin{tabular}{llc}
\hline Items & Alfalfa & Orange pulp \\
\hline DM $(\%)$ & 35 & 25 \\
pH & 6.34 & 5.08 \\
CP & 18.02 & 6.12 \\
ADF & 29.9 & 22.8 \\
NDF & 30.9 & 24.5 \\
WSC & 3.8 & 5.2 \\
\hline
\end{tabular}

ADF: acid detergent fibre, NDF: Neutral detergent fibre, WSC: Water soluble carbohydrate, CP: crude protein, DM: dry matter.

Based on mini silos capasity, the amount of $1750 \mathrm{~g}$ of alfalfa was blended with $750 \mathrm{~g}$ of orange pulp and after adding levels of $0,1.5 \times 10^{8} \mathrm{cfu} / \mathrm{g}, 3 \times 10^{8} \mathrm{cfu} / \mathrm{g}$ and $4.5 \times 10^{8} \mathrm{cfu} / \mathrm{g}$ of the bacterial additive (Lactobacillus boucheri MT40788) was ensiled for 90 days. Distilled water used to dissolve bacterial supplements was added to the control treatment, which was $2.5 \mathrm{~kg}$ of alfalfa forage before the ensiling. The laboratory silos were made of UPVC tubes with a height of $90 \mathrm{~cm}$ and a diameter of $10 \mathrm{~cm}$ with a volume of $2.5 \mathrm{~kg}$. Treatments were 1) alfalfa without any additive (control), 2) alfalfa + OP (70\% alfalfa mixed with $30 \%$ fresh OP, LAB0), 3) treatment 2 with $1.5 \mathrm{~g} \mathrm{LAB} /$ ton (LAB1), 4) treatment 2 with $3 \mathrm{~g}$ $\mathrm{LAB} /$ ton (LAB2) and 5) treatment 2 with $4.5 \mathrm{~g}$ $\mathrm{LAB} /$ ton (LAB3).

At the end of 90 days ensiling, silos were opened and immediately $\mathrm{pH}, \mathrm{DM}$, microbial culture and soluble carbohydrate samples were measured and the remaining samples were stored in the refrigerated room at -20 o $\mathrm{C}$ for subsequent analysis. Acid detergent fibre (ADF) and neutral detergent fibre (NDF) contents were determined with the method described by Van Soest et al. (1991), Crude ash (CA) and crude protein (CP) contents of the resultant silages were determined by the method of AOAC (2000). Water-soluble carbohydrates were determined according to the method described by Dubois et al. (1956). Concentration of VFA of silages were measured according to the method of Filya (2003).
The aerobic stability was measured using the method described by Adesogan et al. (2004). $400 \mathrm{~g}$ of each sample was transferred into containers, and a thermometer was placed in the center of each silage mass and two thermometers in two different points of the room (ambient temperature $12^{\circ} \mathrm{C}$ ). Silage and ambient temperature were recorded manually every two hours until heating occurred. When the silage mass temperature reached $2{ }^{\circ} \mathrm{C}$ above the ambient temperature, silage was considered to be spoiled (Ranjit and Kung 2000).

\section{In situ trail}

Two rumen-cannulated sheeps $(18 \pm 2$ months old, $45 \pm 3 \mathrm{~kg}$ ) were used to study the in situ rumen degradation of the silage. The animals were offered $400 \mathrm{~g}$ lucerne, $200 \mathrm{~g}$ barley and $200 \mathrm{~g}$ soybean meal twice a day at 09:00 $\mathrm{h}$ and 17:00 $\mathrm{h}$ (NRC, 1980). Animals had free access to water. Dried and ground (1 $\mathrm{mm}$ screen) silage samples (three replications) were weighed into polyester nylon bags (Vanzant et al. 1998). The incubation times were $0,2,4,6,8,12$, $16,24,48,72,96 \mathrm{~h}$. There were 4 bags per treatment for every hour.

The animal protocol used in this study was approved by The Research Bioethics Committee of the University of Tabriz, and the study was carried out in accordance with EU Directive 2010/63/EU for animal experiments.

\section{In vitro trial}

The amount of in vitro DM degradation of treatments was measured in bottles (in 3 replications) using the technique described by Fedorak and Hurdy (1983). The amount of DM disappearance of treatments was recorded at 2, 4, 8, 12 and $24 \mathrm{~h}$ post-incubation.

\section{Statistical analysis}

The results of the experiment were analyzed by oneway analysis of variance and treatment means were compared by the Duncan multible range test (SAS, 2002).

\section{RESULTS}

Bacterial innoculation and OP effects on nutritional value of the resultant alfalfa silages are given in Table 2. The results showed that the addition of OP to alfalfa silage reduced $\mathrm{pH}$ compared to control $(\mathrm{P}<0.05)$.

Bacterial additives were also reduced $\mathrm{pH}$ in comparison to control $(\mathrm{P}<0.05)$. This decrease in $\mathrm{pH}$ value was intensified by increasing the use of additives, but no significant difference was observed between 4 different levels tested. The addition of OP to the alfalfa silages increased soluble carbohydrates compared to the control $(\mathrm{P}<0.05)$. The $\mathrm{DM}$ of silages 
was not affected by the bacterial additives or OP.

Total volatile fatty acids in the treatment of alfalfa with OP without bacterial additive increased compared to control $(\mathrm{P}<0.05$; Table 2$)$.

Table 2. The chemical characteristics of experimental silages after $90 \mathrm{~d}$ (\% of DM).

\begin{tabular}{|c|c|c|c|c|c|c|c|c|c|c|}
\hline \multirow{2}{*}{ Itemes } & \multicolumn{5}{|c|}{ Treatments $^{1}$} & \multirow{2}{*}{ SEM } & \multirow{2}{*}{ Trt } & \multicolumn{3}{|c|}{ Contrasts $(\mathrm{P}<)^{3}$} \\
\hline & $\mathrm{CON}$ & LB0 & LB1 & LB2 & LB3 & & & Linear & Quadratic & Cubic \\
\hline $\mathrm{DM}$ & 33.03 & 30.2 & 33.93 & 30.93 & 31.03 & 0.923 & 0.077 & 0.017 & 0.413 & 0.236 \\
\hline WSC & $1.33^{\mathrm{c}}$ & $1.99^{\mathrm{a}}$ & $1.26^{\mathrm{d}}$ & $1.40^{\mathrm{b}}$ & $1.40^{\mathrm{b}}$ & 0.009 & $<0.0001$ & $<0.0001$ & $<0.0001$ & $<0.0001$ \\
\hline tVFA, mM & $13.66^{\mathrm{c}}$ & $18.00^{\mathrm{b}}$ & $18.33^{b}$ & $21.66^{\mathrm{a}}$ & $22.33^{\mathrm{a}}$ & 0.394 & $<0.0001$ & 0.563 & $<0.0001$ & $<0.0001$ \\
\hline $\mathrm{CP}$ & $17.75^{\mathrm{a}}$ & $16.87^{\mathrm{b}}$ & $17.06^{b}$ & $16.31^{\mathrm{c}}$ & $16.18^{\mathrm{c}}$ & 0.95 & $<0.0001$ & $<0.009$ & $<0.0001$ & $<0.0001$ \\
\hline $\mathrm{QI}^{2}$ & 90.87 & 91.53 & 99.40 & 96.20 & 97.46 & 2.613 & 0.163 & 0.0591 & 0.1810 & 0.1393 \\
\hline
\end{tabular}

${ }^{1}$ Treatments; CON: alfalfa with no additive, alfalfa (70\%) with fresh orange pulp (30\%) and treated with LAB for final application rate $0,1.5$, 3 and $4.5 \mathrm{~g}$ LAB inoculant/ton (LB0, LB1, LB2 and LB3, respectively).

${ }^{2}$ Quality index: $220+(2 \times \mathrm{DM} \%-15)-40 \times \mathrm{pH}$.

${ }^{3}$ Significant level of treatment effect.

Within a row, means followed by different letters differ $(\mathrm{P}<0.05)$.

Although OP did not affect the NDF contents of the resultant silages, OP significantly increased $\mathrm{ADF}$ in LB0 compared to the control $(\mathrm{P}<0.05)$. Bacterial additive consumption in all 3 levels decreased ADF compare to LB0 that this reduction was significant $(\mathrm{P}<0.05)$. Addition of $\mathrm{OP}$ and bacterial additives reduced $\mathrm{CP}$ contents of silages compared to the control $(\mathrm{P}<0.05)$.

The effects of inoculation and OP on aerobic stability of wilted alfalfa silages are given in Figure 1. Additional OP to alfalfa silage decreased aerobic stability compared to control and other treatments.

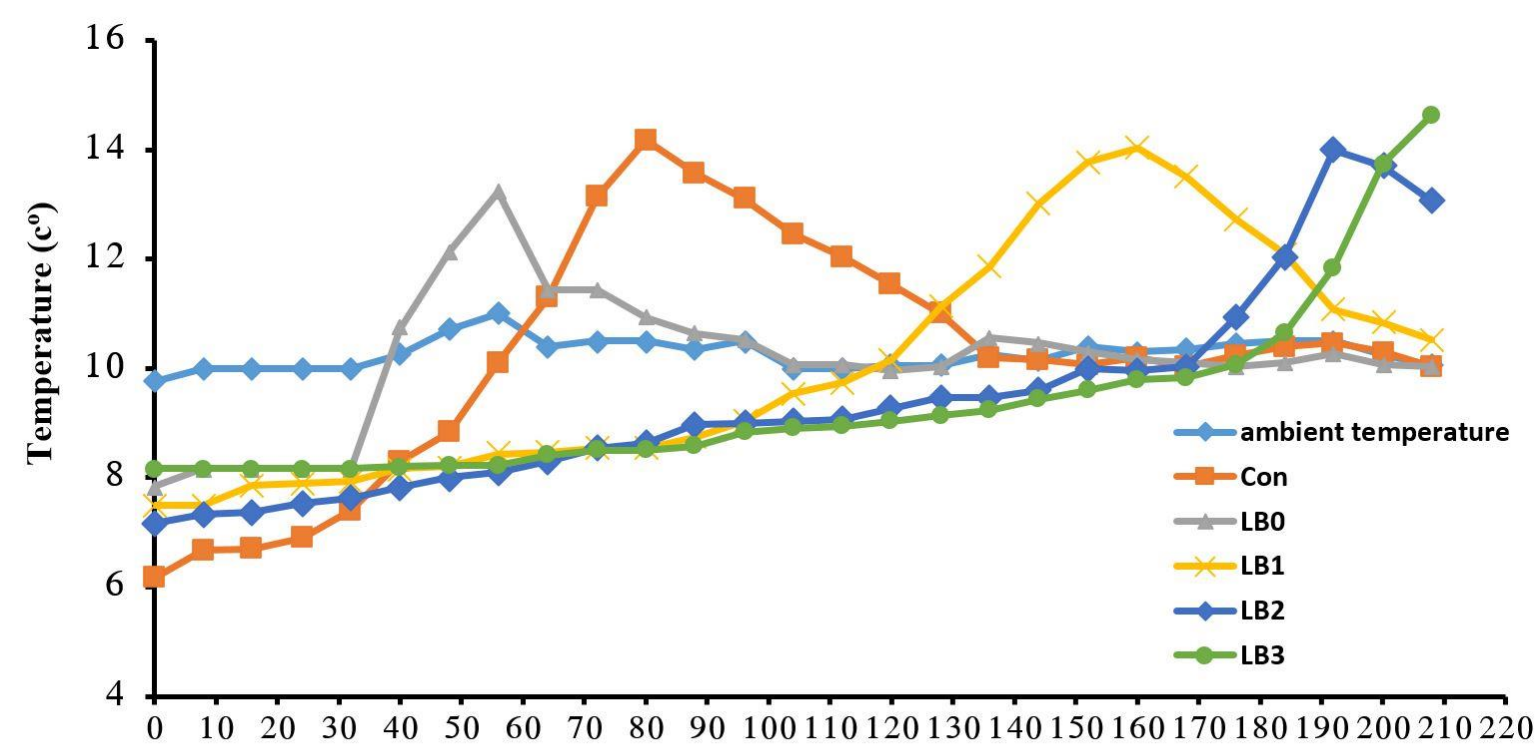

Time of exposure to air (h)

Figure 1. Bacterial additive and orange pulp effects on aerobic stability of alfalfa silages.

The effect of noculation and OP supplementation on bacterial populations of the resultant silages are shown in Table 3. The addition of OP to wilted alfalfa did not affect yeast and fungi population but the OP silage increased the population of lactobacilli and total bacterial numbers compared to the control treatment $(\mathrm{P}<0.01)$. Higher bacterial additives level were significantly decreased the population of yeasts and fungi. This reduction increased with increasing intakes of additives and significant differences were observed among different bacterial treatments $(\mathrm{P}<0.01)$.

Effect of treatments on in situ DM disappearance on incubation times are shown in Table 4 and Figure 2. Adding OP to alfalfa silage significantly increased the dry matter degradation at all incubation times except for $0 \mathrm{~h}(\mathrm{P}<0 / 05)$. Rapidly degraded fraction (a) for LB3 and LB2 was higher than the other treatments, 
Table 3. Effect of treatments on silage microbial population

\begin{tabular}{llll}
\hline Treatments & $\begin{array}{l}\text { SDA } \\
\left(\log 10^{4}\right)\end{array}$ & $\begin{array}{l}\text { MRS } \\
\left(\log 10^{5}\right)\end{array}$ & $\begin{array}{l}\text { NA } \\
\left(\log 10^{6}\right)\end{array}$ \\
\hline CON & $5.10^{\mathrm{ab}}$ & $7.13^{\mathrm{e}}$ & $8.49^{\mathrm{e}}$ \\
LB0 & $5.17^{\mathrm{a}}$ & $7.22^{\mathrm{d}}$ & $8.71^{\mathrm{d}}$ \\
LB1 & $5.06^{\mathrm{ab}}$ & $7.77^{\mathrm{c}}$ & $8.80^{\mathrm{c}}$ \\
LB2 & $4.98^{\mathrm{b}}$ & $7.87^{\mathrm{b}}$ & $8.90^{\mathrm{b}}$ \\
LB3 & $4.55^{\mathrm{c}}$ & $8.03^{\mathrm{a}}$ & $9.08^{\mathrm{a}}$ \\
SEM & 0.03 & 0.01 & 0.01 \\
\hline
\end{tabular}

Treatments; alfalfa with no additive (CON), alfalfa (70\%) with fresh orange pulp (30\%) and treated with LAB for final application rate $0,1.5,3$ and $4.5 \mathrm{~g} \mathrm{LAB}$ inoculant/ton (LB0, LB1, LB2 and LB3, respectively).

Within a row, means followed by different letters differ $(\mathrm{P}<0.05)$ which it shows these treatments had high level of nonstructural carbohydrates (Table 5). All treatments except control had greatest amount of fraction $b$ (insoluble but fermentable component; $\mathrm{P}<0.05$ ).

Effect of treatments on in vitro DM degradation on incubation times are shown in Table 6 and Figure 3. After $24 \mathrm{~h}$ incubation LB0 and control treatments had the highest and lowest DM degradability among treatments, respectively $(\mathrm{P}<0.05)$.

\section{DISCUSSION}

The results showed that the addition OP to alfalfa silage reduce $\mathrm{pH}$ compared to control $(\mathrm{P}<0.05)$. The results obtained in the current study were consistent with the results of Touqir et al. (2007) and Hashemzadeh et al. (2011) who studied the effect of different carbohydrate sources on different silages.

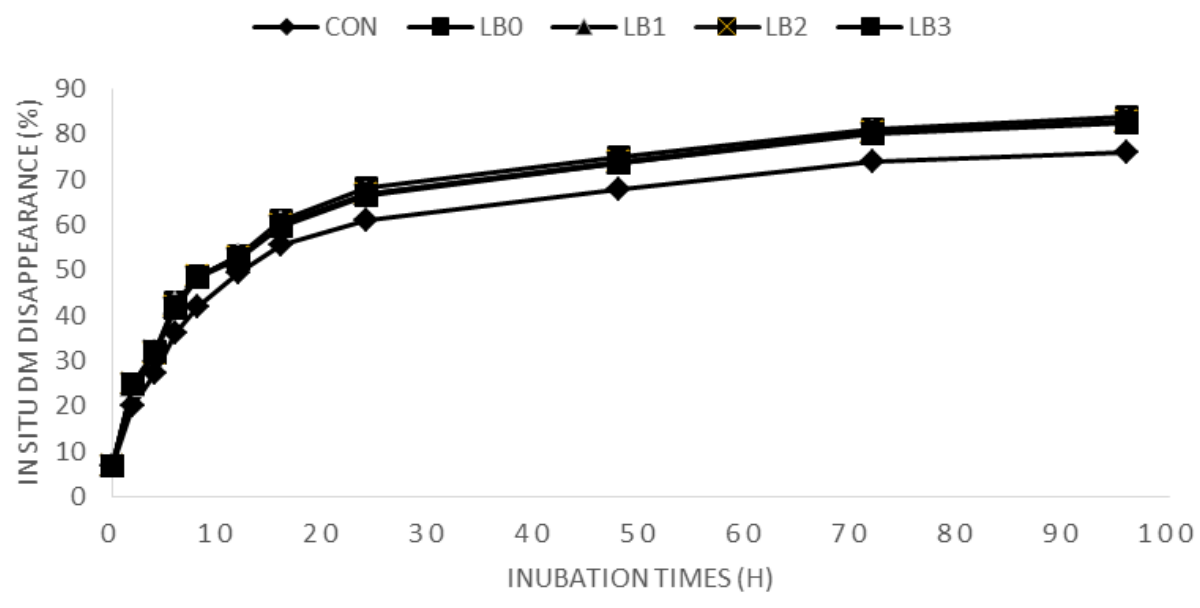

Figure 2. Effect of treatments on in situ DM disappearance on incubation times

Table 4. Effect of treatments on in situ DM disappearance on incubation times (\%)

\begin{tabular}{llllllllllll} 
& \multicolumn{1}{l}{ Incubation times $(\mathrm{h})$} \\
\cline { 2 - 11 } Treatments $^{\dagger}$ & 0 & 2 & 4 & 6 & 8 & 12 & 16 & 24 & 48 & 72 & 96 \\
\hline CON & 6.80 & $20.16^{\mathrm{b}}$ & $27.16^{\mathrm{c}}$ & $36.25^{\mathrm{d}}$ & $41.91^{\mathrm{b}}$ & $49.50^{\mathrm{d}}$ & $55.41^{\mathrm{d}}$ & $61.08^{\mathrm{c}}$ & $67.75^{\mathrm{c}}$ & $74.08^{\mathrm{c}}$ & $76.08^{\mathrm{d}}$ \\
LB0 & 6.81 & $24.75^{\mathrm{a}}$ & $32.16^{\mathrm{a}}$ & $42.83^{\mathrm{a}}$ & $48.41^{\mathrm{a}}$ & $53.33^{\mathrm{a}}$ & $60.91^{\mathrm{a}}$ & $68.16^{\mathrm{a}}$ & $75.00^{\mathrm{a}}$ & $81.16^{\mathrm{a}}$ & $83.75^{\mathrm{a}}$ \\
LB1 & 6.75 & $24.66^{\mathrm{a}}$ & $31.91^{\mathrm{a} b}$ & $42.58^{\mathrm{a}}$ & $48.50^{\mathrm{a}}$ & $53.16^{\mathrm{a}}$ & $60.41^{\mathrm{b}}$ & $66.66^{\mathrm{b}}$ & $73.58^{\mathrm{b}}$ & $80.58^{\mathrm{b}}$ & $82.91^{\mathrm{b}}$ \\
LB2 & 6.73 & $24.83^{\mathrm{a}}$ & $31.83^{\mathrm{b}}$ & $41.91^{\mathrm{b}}$ & $48.58^{\mathrm{a}}$ & $52.66^{\mathrm{b}}$ & $59.83^{\mathrm{c}}$ & $66.66^{\mathrm{b}}$ & $73.83^{\mathrm{b}}$ & $80.33^{\mathrm{b}}$ & $82.83^{\mathrm{bc}}$ \\
LB3 & 6.70 & $24.91^{\mathrm{a}}$ & $32.16^{\mathrm{a}}$ & $41.50^{\mathrm{c}}$ & $48.50^{\mathrm{a}}$ & $52.33^{\mathrm{c}}$ & $59.50^{\mathrm{c}}$ & $66.64^{\mathrm{b}}$ & $73.75^{\mathrm{b}}$ & $80.25^{\mathrm{b}}$ & $82.58^{\mathrm{c}}$ \\
SEM & 0.063 & 0.145 & 0.093 & 0.107 & 0.107 & 0.010 & 0.137 & 0.147 & 0.130 & 0.115 & 0.105 \\
\hline
\end{tabular}

†Treatments; CON: alfalfa with no additive, alfalfa (70\%) with fresh orange pulp (30\%) and treated with LAB for final application rate 0, 1.5, 3 and $4.5 \mathrm{~g}$ LAB inoculant/ton (LB0, LB1, LB2 and LB3, respectively).

Within a row, means followed by different letters differ $(\mathrm{P}<0.05)$.

Bernardes et al. (2005) examined three levels of citrus pulp on Marando silage and had also similar results. Taiwo et al. (1995) ensiled citrus pulp alone and observed a significant reduction in $\mathrm{pH}$ after a 61 -day period. The results obtained in the current study were consistant with findings of Habeeb et al. (2017) and Allam et al. (2020) who used citrus pulp along with forage rye and oats. Volanis et al. (2006) also reported drop in the silage $\mathrm{pH}$ compared to the beginning of the period.
Hashemzadeh et al. (2011) showed that Lalsil bacterial inoculation reduced the $\mathrm{pH}$ but Ecosil did not affect silage $\mathrm{pH}$. Besharati et al. (2017) as a result of the addition of $L$. buchneri to the silage alfalfa after a 90-day period were reported to reduce the $\mathrm{pH}$ in the treatments. Nishino et al. (2004) and Kizilsimsek et al. (2007) reported similar results. Filya (2003), Schmidt et al. (2009) and Yanbing and Naoki (2011) and reported results contrary to our results. In general, the lower $\mathrm{pH}$ of treatment compared to the control is the highest level of soluble carbohydrates 
Table 5. Effect of treatments on in situ degradability parameters

\begin{tabular}{llll}
\hline & \multicolumn{3}{c}{ Parameters } \\
\cline { 2 - 4 } Treatments & $\mathrm{a}$ & $\mathrm{b}$ & $\mathrm{c}$ \\
\hline CON & $9.11^{\mathrm{c}}$ & $63.48^{\mathrm{b}}$ & $0.084^{\mathrm{c}}$ \\
LB0 & $11.09^{\mathrm{b}}$ & $67.19^{\mathrm{a}}$ & $0.088^{\mathrm{ab}}$ \\
LB1 & $11.05^{\mathrm{b}}$ & $67.35^{\mathrm{a}}$ & $0.089^{\mathrm{a}}$ \\
LB2 & $11.24^{\mathrm{ab}}$ & $67.27^{\mathrm{a}}$ & $0.087^{\mathrm{b}}$ \\
LB3 & $11.36^{\mathrm{a}}$ & $66.99^{\mathrm{a}}$ & $0.087^{\mathrm{b}}$ \\
SEM & 0.082 & 0.575 & 0.0005 \\
\hline
\end{tabular}

†Treatments; CON: alfalfa with no additive, alfalfa (70\%) with fresh orange pulp (30\%) and treated with LAB for final application rate $0,1.5,3$ and $4.5 \mathrm{~g} \mathrm{LAB}$ inoculant/ton (LB0, LB1, LB2 and LB3, respectively).

Within a column, means followed by different letters differ $(\mathrm{P}<0.05)$. and high availability of nutrients for domination of lactic acid bacteria and production of lactic acid and VFA, that lactic acid by increasing the concentration of $\mathrm{H}^{+}$, can reduce the level of silage $\mathrm{pH}$ to the intolerable range for harmful bacteria.

In the current study, DM contents of the resultant silages was not affected by the bacterial additives or OP. This result is in agreement with findings of Filya (2003); Kung et al. (2003),), Bernardes et al. (2005), Filya et al. (2007) and Schmidt et al. (2009) and Hashemzadeh et al. (2011) with the addition of citrus pulp to Marando forage reported numerical increase in the WSC that the number of increased is nonsignificant.

Table 6. Effect of treatments on in vitro DM digestibility (\%)

\begin{tabular}{llllll}
\hline & \multicolumn{5}{c}{ Incubation times $(\mathrm{h})$} \\
\cline { 2 - 6 } Treatments & 2 & 4 & 8 & 12 & 24 \\
\hline CON & $12.44^{\mathrm{b}}$ & $22.05^{\mathrm{c}}$ & $30.77^{\mathrm{c}}$ & $37.55^{\mathrm{c}}$ & $52.44^{\mathrm{d}}$ \\
LB0 & $18.66^{\mathrm{a}}$ & $28.50^{\mathrm{a}}$ & $37.22^{\mathrm{a}}$ & $44.88^{\mathrm{a}}$ & $62.55^{\mathrm{a}}$ \\
LB1 & $18.77^{\mathrm{a}}$ & $28.61^{\mathrm{a}}$ & $36.88^{\mathrm{a}}$ & $44.77^{\mathrm{a}}$ & $61.77^{\mathrm{b}}$ \\
LB2 & $18.77^{\mathrm{a}}$ & $27.61^{\mathrm{b}}$ & $35.00^{\mathrm{b}}$ & $43.11^{\mathrm{b}}$ & $59.44^{\mathrm{c}}$ \\
LB3 & $18.55^{\mathrm{a}}$ & $27.77^{\mathrm{b}}$ & $34.77^{\mathrm{b}}$ & $42.77^{\mathrm{b}}$ & $59.44^{\mathrm{c}}$ \\
SEM & 0.09 & 0.15 & 0.15 & 0.11 & 0.22 \\
\hline
\end{tabular}

$\nmid$ Treatments; alfalfa with no additive (CON), alfalfa (70\%) with fresh orange pulp (30\%) and treated with LAB for final application rate 0, 1.5, 3 and $4.5 \mathrm{~g}$ LAB inoculant/ton (LB0, LB1, LB2 and LB3, respectively).

Within a column, means followed by different letters differ $(\mathrm{P}<0.05)$.

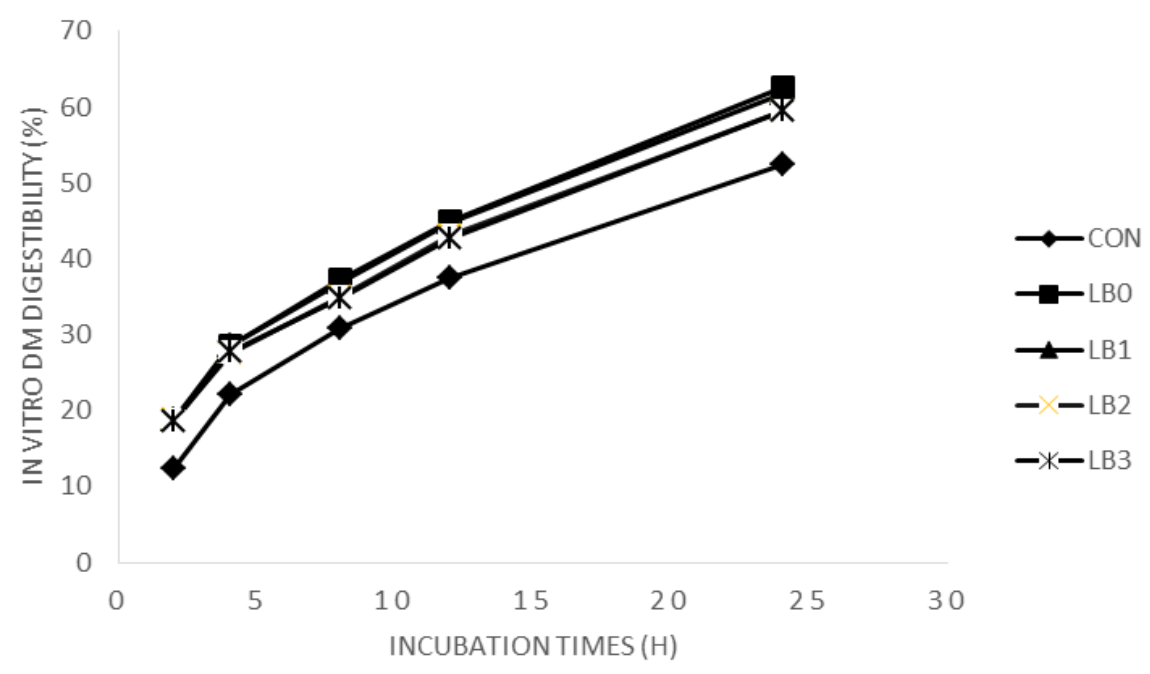

Figure 3. Effect of treatments on in vitro DM digestibility (\%)

This is probably due to the use of citrus pulp in that experiment was much lower than our test. The results of studies by Silva (2002), who was ensiled Tanzania forage along with citrus pulp for 60 days also conformed. Silva (2002) reported that the addition of $120 \mathrm{~g}$ per $\mathrm{kg}$ of dry matter from the peels to feed increased 3 percent is soluble carbohydrate. Asadi et al. (2002) and Hashemzadeh et al. (2011), used a carbohydrate source such as molasses cause to increase the amount of soluble carbohydrates compared to control. Bacterial additive reduces the amount of soluble carbohydrates compare to LB0 $(\mathrm{P}<0.05)$. Besharati et al. (2017) examined the effects of L. Buchneri alone and in combination with molasses at different levels in a 90-day period on alfalfa silage, reported the reduction in soluble carbohydrates in L. Buchneri treatment compared to the control. Our result corresponded with Filya (2003) studied the effects of L. Buchneri, L. Plantrum and a 
mixture of the two bacteria on three forage maize, sorghum and wheat silage in a 60-day period. In another experiment, the effect of 14 different additive bacterial includes two types of $L$. Buchneri on the first and second cutting alfalfa silage were examined by Filya (2003), in first cut all of additives declined soluble carbohydrates compared to the control, in the second cut, both of L. Buchneri along with 6 other additives reduce and 6 other additives increase in soluble carbohydrates than the control treatment. This results with the results of Kung et al. (2003), Schmidt et al. (2009) and many other tests that the effects of adding L. Buchneri examined on different silage, was consistent. The reduction in soluble carbohydrates can interpreted by increase bacterial activity and fermentation to produce organic acids.

Total volatile fatty acids in the treatment of wilted Alfalfa with OP without bacterial additives increased compared to control $(\mathrm{P}<0.05$; Table 2). Hashemzadeh et al. (2011), were investigated the addition of molasses to wilted alfalfa reported increases in the total amount of the volatile fatty acids. Increase in total volatile fatty acids in other studies such as Islam et al. (2001), Asadi et al. (2002), Aksu et al. (2006), Khan et al. (2006), that they looked the effect of different sources of carbohydrate on different silage have been reported. Bacterial additives at levels lower than manufactory recommended could not cause significant changes to the LB0 but in 2 other levels of bacterial additives, the total volatile fatty acids rose compared to other treatments $(\mathrm{P}<0.05)$. The results in agreement with the results of Baytok et al. (2005), Kleinschmit and Kung (2006), Filya et al. (2007), Liu et al. (2016), Besharati et al., (2017) and Koç et al. (2020). Evaluated 14 types of bacterial additive on the first cutting of alfalfa hay, reported that all additives increased VFA. The increase in total volatile fatty acids can be attributed with high populations of LAB and the availability of carbohydrate source to produce organic acids such as lactic acid and acetic acid in the treatments compared to the control.

Bacterial additives at all 3 levels compared to control treatment did not cause a change in the NDF. Ranjit and Kung (2000), Asadi et al. (2002), Kizilsimsek et al. (2007), Hashemzadeh et al. (2011) and Besharati et al., (2017) reported similar results with the results of the current study. In Filya et al. (2007) studied, at 6 additives an increase in the NDF, 5 additives without change and 3 additives reported a decrease in the NDF compared to control. In the second stage of this study on the second cutting alfalfa forage 10 additives decreased, 2 Additives increased and 2 additives unchanged compared to the control.

Orange pulp significantly increased ADF in LB0 compared to the control $(\mathrm{P}<0.05)$. Bacterial additive consumption in all 3 levels decreased ADF compare to
LB0 significantly $(\mathrm{P}<0.05)$. In Ranjit and Kung (2000) experiment consumption, low level of L. Buchneri was reduced ADF. In a study conducted by Kung and Ranjit (2001) L. Buchneri additives used at 3 levels on barley hay, which reduces numerically $\mathrm{ADF}$ in 100-day silage. Hashemzadeh et al. (2011), , Adesogan et al. (2004), Khorvash et al. (2006) ; Kizilsimsek et al. (2007), Besharati et al., (2017), in a different experimental reported reduction in the $\mathrm{ADF}$ that affected by bacterial inoculant.

Addition of $\mathrm{OP}$ and bacterial additives caused to reduce crude protein (CP) compared to the control $(\mathrm{P}<0.05)$. This is possibly due to low crude protein content in OP. Hashemzadeh et al. (2011) in their study on the effect of adding molasses to alfalfa reported a reduction in crude protein content with increasing levels of molasses. Bacterial additives at low levels control did not cause a change in the amount of crude protein compared to LB0, but at higher levels of additives reduced crude protein than the LB0 treatment $(\mathrm{P}<0.05)$. Addition of $\mathrm{OP}$ and bacterial additives caused to improve silage quality index compared to the control. Uher et al., (2019) bacterial inoculant treatments had lower values of $\mathrm{ADF}, \mathrm{NDF}$ and $\mathrm{pH}$ and significantly lower values butyric acid, alcohols and $\mathrm{NH}_{3}-\mathrm{N} /$ total nitrogen compared to control silage and showed that bacterial inoculant increases silage quality compared to control silage.

Additional OP to alfalfa silage decreased aerobic stability compared to control and other treatments. The aerobic stability in all L. Buchneri additives were used increased compare to control and LB0 treatment that this rate of increase in aerobic stability, improve by increasing the amount of L. Buchneri (LB1, LB2 and LB3, 144,192 and 200, respectively).

Current results were well correlated with the results of Ranjit and Kung (2000) were studied L. Buchneri at 2 levels on corn silage. Driehuis et al. (2001) in three different experiments examined L. Buchneri additives alone and in combination with $L$. Plantrum on forage grasses in the 90 and 180-day periods. In all trials, both $L$. Buchneri and in combination with $L$. Plantrum improved aerobic stability, and the positive response continued by increasing amount of $L$. Buchneri, up to 480 hours of exposure to air. Filya (2003) were evaluated the effects of $L$. Buchneri alone and in combination with $L$. Plantrum on wheat, sorghum and maize that in all treatments improve aerobic stability were reported. Our results with the results of Ranjit and Kung (2000), Driehuis et al. (2001) matched. In general impact on improving aerobic stability of L. Buchneri can be interpreted by increased acetic acid bacteria and also reduce the amount of residual soluble carbohydrates and less accumulation of lactic acid and ammonia nitrogen.

The Addition of OP to wilted alfalfa caused a little 
numerical increase in population of yeasts and fungi that the increase was not significant compared to the control treatment $(\mathrm{P}>0.01)$ but the OP silage increased the population of lactobacilli and total bacterial numbers compared to the control treatment $(\mathrm{P}<0.01)$. This can be explained by an increase in carbohydrate resources available for growth all microbial species present in the silage. Bacterial additives in their higher level were significantly decreased the population of yeasts and fungi, that this reduction, increased with increasing intakes of additives and significant differences were observed among different bacterial treatments $(\mathrm{P}<0.01)$. Also, bacterial additives caused to increase the population of lactobacilli and total bacterial numbers in the silage compare to treatment LAB0. This increase has a direct and significant relation with higher amounts of bacterial additives that used $(\mathrm{P}<0.01)$. Schmidt et al. (2009) examined the effects of L. Buchneri alone or in combination with Pedico cocos pantesose on total bacterial numbers in 120-day period on corn silage in six different geographic regions, reported a significant increase in the total population of lactic acid bacteria and significantly reduced in yeasts and fungi population. The trial results also matched with the results of Nishino et al. (2004) study. Kizilşimşek et al. (2020) showed that bacterial inoculation decreased the $\mathrm{pH}$ level, increased the production of lactic acid, whereas decreased the acetic acid, propionic acid and butyric acid in silage content. L. brevis strain as well as wilting can be used successfully in alfalfa silage production when crude protein and lactic acid production in silage were taken into consideration. Dumlu Gül et al. (2015) suggested that in order to make successful silage from alfalfa, addition of molasses + rolled barley, cutting alfalfa in late flowering and wilting after cutting can be useful.

Adding OP to alfalfa silage did not caused any effect on DM digestibility at $0 \mathrm{~h}$ of the test, but from $2 \mathrm{pm}$ to 96 hours significantly increased digestibility compared to control treatment (Table 4) $(\mathrm{P}<0.05)$. The increase in digestion, similar to other studies that used different sources of carbohydrates, due to higher soluble carbohydrate content of this treatment seems reasonable. Overall degradation due to the break in the silage treated with molasses Ligno celluloses links between structural composition and amount of soluble carbohydrates in this category silage (Rowghani and Zamiri, 2009). Bacterial additives at a low level until $12 \mathrm{~h}$ demonstrated no change in digestion compare to LB0, but from $12 \mathrm{~h}$ to $96 \mathrm{~h}$ was significantly reduced digestibility (Table 4) $(\mathrm{P}<0 / 05)$. At higher levels of additives from $6 \mathrm{~h}$ to the end of trial except $8 \mathrm{~h}$, significant reductions were observed in digestibility compare to LB0 (Table 4) $(\mathrm{P}<0 / 05)$. Haghparvar et al. (2012) that examined the effect of the addition $L$. Plantrum to corn silage at three stages of maturity in a 25-day period, founded that Bacterial additive in the third stage of maturity increased degradation of a section and reduced degradation of $b$ section compare to the control. The researchers explained increase of degradation in a section and decrease of a degradation in $\mathrm{b}$ section by bacterial activity and decomposition Lignocellulose of the cell wall and providing nutrients for the rumen bacteria. Vatandost et al. (2011) by adding L. Plantrum to sorghum silage over a period of 40 days, reported a significant reduction in degradation of a section and increased degradation of $b$ section.

Rapidly degraded fraction (a) for LB3 and LB2 was higher than the other treatments, which showeed treatments had high level of nonstructural carbohydrates (Table 5). All treatments except control had greatest amount of fraction $b$ (insoluble but fermentable component; $\mathrm{P}<0.05$ ). The LAB strains used in the study of Ertekin and Kızılşimşek (2020), positively affected fermentation properties and feed quality parameters of treatments compared to control.

\section{CONCLUSION}

Results of this study ndicated that LAB can improve the aerobic stability and silage quality in laboratory silos and also, OP and LAB might improve silage quality and cause a better management of alfalfa silage in farms.

\section{Ethical statement}

None of the animals were harmed during the collection of in situ trial and in vitro trials.

\section{Conflict of interest}

We have declared no conflict of interest.

\section{REFERENCE}

Adesogan AT, Krueger N, Salawu MB, Dean DB, Staples CR 2004. The influence of treatment with dual purpose bacterial inoculants or soluble carbohydrates on the fermentation and aerobic stability of bermudagrass. J Dairy Sci 87(10): 3407-3416.

Aksu T, Baytok E, Karsli MA, Muruz H 2006. Effects of formic acid, molasses and inoculant additives on corn silage composition, organic matter digestibility and microbial protein synthsis in sheep. Small Rumin Res 61(1): 29-33.

Alnaimy A, Gad AE, Mustafa MM, Atta MAA, Basuony HAM 2017. Using of citrus by-products in farm animals feeding. Open Access J Sci. 1(3):5867. DOI: 10.15406/oajs.2017.01.00014

Anonim 2016. Minimizing yeast growth in silage. https://www.dairyherd.com/article/minimizingyeast - growth-silage

AOAC 2000. Official Methods of Analysis (17th ed.): . 
Association of Official Analytical Chemists, Inc., Arlington, Virginia, USA.

Asadi ME, Clemente RS, Gupta AD, Loof R, Hansen GK 2002. Impacts of fertigation via sprinkler irrigation on nitrate leaching and corn yield in an acid-sulfate soil in Thailand. Agric. Water Manage 52(3): 197-213.

Ayaşan T, İnci H 2019. Use of citrus co-products in anımal nutrition. ISPEC 3. International conference on agriculture, animal science and rural development-III. 20-22 December 2019, Van. pp:524-536.

Baytok E, Aksu T, Karsli MA, Muruz H 2005. The effects of formic acid, molasses and inoculant as silage additives on corn silage composition and ruminal fermentation characteristics in sheep. Turk J Vet Anim Sci 29 (2): 469-474.

Benchaar C, Petit HV, Berthiaume R, Ouellet DR, Chiquette J, Chouinard P Y 2007. Effects of essential oils on digestion, ruminal fermentation, rumen microbial populations, milk production, and milk composition in dairy cows fed alfalfa silage or corn silage. Journal of Dairy Sci 90(2): 886-897.

Bernardes TF, Reis RA, Moreira AL 2005. Fermentative and microbiological profile of marandu-grass ensiled with citrus pulp pellets. Scientia Agricola 62(3): 214-220.

Besharati M, Shafipour N, Abdi E, Nemati Z 2017. Effects of supplementation alfalfa silage with molasses, orange pulp and Lactobacillus buchneri on in vitro dry matter digestibility and gas production. J Bio Biotech 6(1): 43-47.

Delavar, MH, Danesh Mesgaran M 2004. Chemical and digestive (ruminal and intestinal) components of treated alfalfa silage with urea and sulfuric acid and their effects on milk production and composition of dairy cows. J Agri Indus Sci 17(3): 231-219.

Dubois M, Giles KA, Hamilton JK, Rebers PT, Smith F 1956. Colorimetric method for determination of sugars and related substances. Anal Chem 28(3): 350-356.

Dumlu Gül Z, Tan M, Fayetörbay Kaynar D, Kharazmi K 2015. Effects of Some Additives. Harvest stage and wilting on quality Characteristics of Alfalfa Silage. Atatürk Üniv J of the Agricultural Faculty 46 (2): 113-118.

Ertekin I, Kızılşimşek M 2020. Effects of Lactic Acid Bacteria Inoculation in Pre-Harvesting Period on Fermentation and Feed Quality of Alfalfa Silage. Asian-Australian Journal of Animal Science 33 (2): 245-253.

Fedorak PM, Hrudey DE 1983. A simple apparatus for measuring gas production by methanogenic cultures in serum bottles. Environ Technol 4(10): 425-432.

Filya I 2003. The effect of lactobacillus buchneri and lactobacillus plantarum on the fermentation, aerobic stability, and ruminal degradability of low dry matter corn and sorghum silages. J Dairy Sci 86(11): 3575-3581.

Filya I, Muck RE, Contreras-Govea FE 2007. Inoculant effects on alfalfa silage: fermentation products and nutritive value. J Dairy Sci 90(11): 5108-5114.

Haghparvar R, Shojaian K, Rowghani E, Parsaei S, Yousef EM 2012. The effects of Lactobacillus plantarum on chemical composition, rumen degradability, in vitro gas production and energy content of whole-plant corn ensiled at different stages of maturity. Iranian J Veterinary Res 13(1): 8-15.

Hashemzadeh-Cigari F, Khorvash M, Ghorbani GR, Taghizadeh, A 2011. The effects of wilting, molasses and inoculants on the fermentation quality and nutritive value of lucerne silage. South African J Anim Sci 41(4): 377-388.

Islam M, Enishi O, Purnomoadi A, Higuchi K, Takusari N, Terada F 2001. Energy and protein utilization by goats fed Italian ryegrass silage treated with molasses, urea, cellulase or cellulase + lactic acid bacteria. Small Rminant Res 42(1): 49-60.

Jalč D, Lauková A, Kišidayová S 2010. Effect of inoculants on fermentation parameters and chemical composition of grass and corn silages. Czech J Anim Sci 43(3): 141-146.

Jalč D, Lauková A, Simonová M, Váradyová Z, Homolka P 2009. The use of bacterial inoculants for grass silage: their effects on nutrient composition and fermentation parameters in grass silages. Czech J Anim Sci 54(2): 83-90.

Karimi M, Besharati M, Taghizadeh A, Safari R 2017. Effects of lactobacillus inoculants on characteristics and composition of alfalfa wilted by orange pulp silage. Anim Prod Res 6(1): 27-37.

Khan MA, Sarwar M, Nisa M, Iqbal Z, Khan MS, Lee WS, Lee HJ, Kim HS 2006. Chemical composition, in situ digestion kinetics and feeding value of Oat grass (Avena sativa) ensiled with molasses for Nili-Ravi Buffaloes. Asian-Aust. J Anim Sci 19(8): 1127-1133.

Khorvash M, Colombatto D, Beauchemin KA, Ghorbani GR, Samei A 2006. Use of adsorbants and inoculants to enhance the quality of corn silage. Can J Anim Sci 86(1): 97-107.

Kizilsimsek M, Adem E, Dönmez R, Katranci, B 2016. Silaj mikro florasının birbirleri ile ilişkileri, silaj fermentasyonu ve kalitesi üzerine etkileri. Tarim ve Doga Dergisi, 19 (2): 136.

Kızılşimşek M, Keklik K, Günaydın T 2020. Using possibilities of new lactic acid bacteria isolates as microbial inoculant on different dry matter containing alfalfa (medicago sativa 1.) silage. KSÜ Tarım ve Doğa Derg 23 (5): 1331-1339. 
Kizilsimsek M, Schmidt RJ, Kung JrL 2007. Effects of a mixture of lactic Acid bacteria applied as a freeze-dried or fresh culture on the fermentation of alfalfa silage. J. Dairy Sci 90(12): 5698-5705.

Kleinschmit DH, Kung JrL 2006. A meta-analysis of the effects of lactobacillus buchneri on the fermentation and aerobic stability of corn and grass and small-grain silages. J Dairy Sci 89(10): 4005-4013.

Koç F, Karapınar B, Okuyucu B, Korucu Erdem D 2020. Kefir Ilavesinin Yonca Silajlarının Fermantasyon Özellikleri ve Aerobik Stabilitesi Üzerine Etkileri. KSU Tarım ve Doğa Derg 23(2): 535-542.

Kowsar R, Ghorbani GR, Alikhani M, Khorvash M, Nikkhah A 2008. Corn silage partially replacing short lucerne hay to optimize forage use in total mixed rations for lactating cows. J Dairy Sci 91(12): 4755-4764.

Kung JrL, Ranjit NK 2001. The effect of lactobacillus buchneri and other additives on the fermentation and aerobic stability of barley silage. J Dairy Sci 84(5): 1149-1155.

Kung JrL, Taylor CC, Lynch MP, Neylon JM 2003. The effect of treating alfalfa with lactobacillus buchneri 40788 on silage fermentation, aerobic stability, and nutritive value for lactating dairy cows. J Dairy Sci 86(1): 336-343.

Liu C, Lai Y, Lu X, Guo P, Luo H 2016. Effects of Lactic Acid Bacteria Inoculants on Alfalfa (Medicago sativa L.) Silage Quality: Assessment of Degradation (in situ) and Gas Production (in vitro). Journal of Integrative Agriculture 15(12): 2834-2841.

Mut H, Gülümser E, Çopur Doğrusöz M, Başaran, U 2020. Değişik Arkadaş Bitkilerin Yonca Silaj Kalitesine Etkisi. KSÜ Tarım ve Doğa Derg 23 (4): 975-980. DOIः 10.18016/ ksutarimdoga.vi.669234.

Nishino N, Wada H, Yoshida M, Shiota H 2004. Microbial Counts, Fermentation Products, and Aerobic Stability of Whole Crop Corn and a Total Mixed Ration Ensiled With and Without Inoculation of Lactobacillus casei or Lactobacillus buchneri. J Dairy Sci 87(8): 2563-2570.

Oude Elferink SJWH, Krooneman J, Gottschal JC, Spoelstra SF, Faber F, Driehuis F 2001. Anaerobic conversion of lactic acid to acetic acid and 1, 2propanediol by Lactobacillus buchneri. Appl Environ Microbiol 67(1): 125-132.

Rowghani E, Zamiri MJ 2009. The effects of a microbial inoculant and formic acid as silage additives on chemical composition, ruminal degradability and nutrient digestibility of corn silage in sheep. Iranian J Vet Res 10(2): 27-35.

Sadeghi K, Khorvash M, Ghorbani GR, Forouzmand MA, Boroumand M, Hashemzadeh, CF 2012. Effects of homo-fermentative bacterial inoculants on fermentation characteristics and nutritive value of low dry matter corn silage. Iranian $\mathrm{J}$ Veterinary Res 13(4): 303-309

SAS 2002. Statistical Analysis System Version 9.1, SAS Institute Inc., Cary, N.C., USA.

Schmidt RJ, Hu W, Mills JA, Kung Jr L 2009. The development of lactic acid bacteria and Lactobacillus buchneri and their effects on the fermentation of alfalfa silage. J Dairy Sci 92(10): 5005-5010.

Silva, CL 2002. Perfil de fermentação das silagens de capim-Tanzânia com aditivos. Lavras: UFLA. (Dissertação - Mestrado).

Sinclair WB 1984. Biochemistry and physiology of the lemon and other citrus fruits. Food and Agriculture Organization of the United Nations.

Soltani A, Ghorbani GR, Alikhani M, Samie A, Nikkhah A 2009. Ground versus steam-rolled barley grain for lactating cows: A clarification into conventional beliefs. J Dairy Sci 92(7): 3299-3305.

Taiwo AA, Adebowale EA, Greenhalgh JFD, Akinsoyinu AO 1995. Techniques for trapping ammonia generated from urea treatment of barley straw. Anim Feed Sci Technol 56(1-2): 133-141.

Touqir NA, Ajmal Khan M, Sarwar M, Nisa M, Lee WS, Lee HJ, Kim HS 2007. Influence of varying dry matter and molasses levels on berseem and lucerne silage characteristics and their in situ digestion Kinetics in Nili buffalo bulls. Asian-Aust J Anim Sci 20(6): 887-893.

Uher D, Konjačić M, Jareš D, Maćešić D 2019. The effect of bacterial inoculant on chemical composition and fermentation of alfalfa silage. $\mathrm{J}$ Central Eur Agri 20(2): 657-664.

Van Soest PJ, Robertson JB, Lewis BA 1991. Methods of dietary fiber, neutral detergent fiber, and nonstarch polysaccharides in relation to animal nutrition. J Dairy Sci 74(10): 3583-3597.

Vanzant ES, Cochran RC, Titgemeyer EC 1998. Standardization of in situ techniques for ruminant feedstuff evaluation. J Anim Sci 76(10): 2717-2729.

Vatandoost M, Danesh Mesgaran M, Vakili AR 2011. Fermentation characteristics, in situ rumen degradation and nutritional value of whole crop barley ensiled with microbial inoculant or ammonium propionate for lactating dairy holstein cows. J Agricul Sci Technol 1(11): 1095-1102.

Volanis M, Zoiopoulos P, Panagou E, Tzerakis C 2006. Utilization of an ensiled citrus pulp mixture in the feeding of lactating dairy ewes. Small Rumin Res 64(1): 190-195.

Woolford MK 1990. The detrimental effects of air on silage. J Appl Bacteriol 68(2): 101-116.

Yanbing L, Naoki N 2011. Effects of inoculation of Lactobacillus rhamnosus and Lactobacillus buchneri on fermentation, aerobic stability and microbial communities in whole crop corn silage. Japanese Society of Grassland Science, Grassland Sci 57(4): 184-191. 